Jpn. J. Crop Sci. 66(3) : 418-426 (1997)

\title{
Quantitative Analysis of the Architecture of Seminal Root System of Rice (Oryza sativa L.) Grown under Different Soil Moisture Conditions*
}

\author{
Yasuhiro Izumi, Yasuhiro Kono, Akira Yamauchi and Morio IIjima \\ (School of Agriculture, Nagoya University, Chikusa, Jvagoya 464-01, Japan) \\ Received January 5, 1996
}

\begin{abstract}
We analyzed and compared the development of the seminal root systems (seminal root axis and lateral roots) of seven rice cultivars grown under two different soil moisture conditions (upland and paddy treatment). The aim was to elucidate cultivar variation and environmental effects with emphasis on the configuration determined by the emergence and elongation of lateral roots (architecture). After growing in a root box for three weeks, the seminal root systems were sampled. The architectures were evaluated using topological, geometrical and fractal analyses in parallel with developmental analysis. Root system development laid emphasis on branching (emergence) of lateral roots under upland treatment and their elongation under paddy treatment. The cultivar variations in total root length were mainly due to variations in total root number and average external link length in the former and latter treatments, respectively, which are similar to those emphasized in each treatment. We found it possible to determine morphological differences in root systems among cultivars or treatments using mathematical parameters. However, we also found that to evaluate a root system architecture exactly, two features of the "complexity of branching pattern" must be understood (i.e., the degree of higher branching order and the frequency of lateral root branching using two parameters, such as topological indices and branching density). Furthermore, the significance of fractal dimension must be clarified according to the strategy of root system development.
\end{abstract}

Key words : Cultivar variation, Fractal dimension, Lateral root, Link length, Rice, Root system architecture, Soil moisture, Topological index.

異なる土壤水分条件下で発達した水稲種子根系における形態の定量的解析 : 泉 泰弘・河野恭廣・山内 章・ 飯嶋盛雄 (名古屋大学農学部)

要 旨: 畑地区 (週 1 回潅水) と湛水区（常時湛水）という $2 つ の$ 実験区を設け, 改良根箱法によって水稲 7 品種を 3 週間生育させた後に根系を採取し，とくに種子根系（種子根軸とそこから発生している側根）を 調查対象として，側根の発生と発達によって規定される形態（根系構造）の定量的解析を行った。そして, 種子根系の形態的特徵を品種間および処理区間で比較することによって，根系発達における品種間差異なら

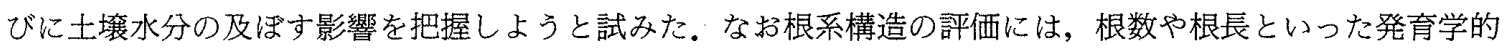
形質の測定と併せて, 数学的な解析法（トポロジー解析，フラクタル解析，幾何学的解析）も採用した。根 系発達様式は畑地区では側根の分枝，湛水区では側根の伸長が優先されており全く異なっていた。また総根 長にみられる品種間差異は, 主に畑地区では総根数の違い, 湛水区では平均外部りンク長の違い (平均側根 長を反映), すなわちそれぞれの区での根系発達において比重が置かれていた点での変異に起因していた. 数学的解析による指標を用いて, 品種間や処理区間における根系の形態的特徴を把握できる可能性を認めた が，同時に根系構造を正確に評価するためには，トポロジー指数と発根密度を用いて “根系分枝の複雑さ” を分枝の高次化の程度と発生頻度の両面から捉えること, 必ずしも一定ではないフラクタル次元の内包する 意味を根系の発達様式纪応じて解积することが必要であることも明らかとなった。

キーワート゚: イネ, 根系構造, 側根, 土壤水分, トポロジー指数, 品種間差異, フラクタル次元, リンク 長.

Phenotypic expression in the development of plant root system is a function of genotypic and environmental factors. In the case of rice (Oryza sativa L.), many studies concerning root system development which focus on main axes (seminal and nodal roots) have been

* An outline of this paper was presented in the 200th meeting of the Crop Science Society of Japan, in November, 1995. conducted ${ }^{19)}$, whereas the configuration determined by emergence and elongation of lateral roots (we use the term "architecture" according to Lynch ${ }^{18)}$ ) has not been paid intensive attention, though the arrangement of lateral roots in soil is a very important factor for acquisition of water and nutrition ${ }^{6,28)}$. Hence, information concerning genotypic variation in root system architecture is very limited ${ }^{12,26)}$ 
compared with that in development of nodal and seminal root axes ${ }^{7,21,29,30)}$.

In this study, we analyzed the architecture of seminal root systems (seminal root axis and lateral roots) of several rice cultivars grown in a root box. Following the opinion that root growth in any one environment cannot reveal the extent of genetic variation among the entries (species or cultivars) ${ }^{22)}$, we compared root system development under both upland and submerged conditions. Soil moisture has been known to be one of the major factors to affect root system development ${ }^{17,19,25)}$, but its effect on architecture is not fully understood by a lack of quantitative analysis. Therefore, we aimed to elucidate the effect of soil moisture as well as cultivar variation.

To quantitatively evaluate root system architecture, topological, geometrical and fractal analyses have been conducted ${ }^{4,5,8,9}$, $10,13,14,27)$ in parallel to the measurement of developmental root characters, such as number, length, etc. It is possible to express the characteristics of root system in a simple way with relatively few parameters in these analyses. Thus, we applied these analytical methods, which have never been used to examine rice root systems grown in soil, and discussed how they were useful for the purpose of this study, namely, to investigate the cultivar variation and effect of soil moisture.

\section{Materials and Methods}

Seven paddy rice cultivars in the pedigree diagram shown in Fig. 1 were grown in root boxes $\{24 \mathrm{~cm}(\mathrm{w}) \times 2 \mathrm{~cm}(\mathrm{~d}) \times 40 \mathrm{~cm}(\mathrm{~h})\}$. Yukara, Peta and Tongil is japonica, javanica and japonica-indica hybrid cultivar, respectively. The other cultivars, Dee-Geo-Woo-Gen (DGWG), IR-8, Taichung Native 1 (TN-1)

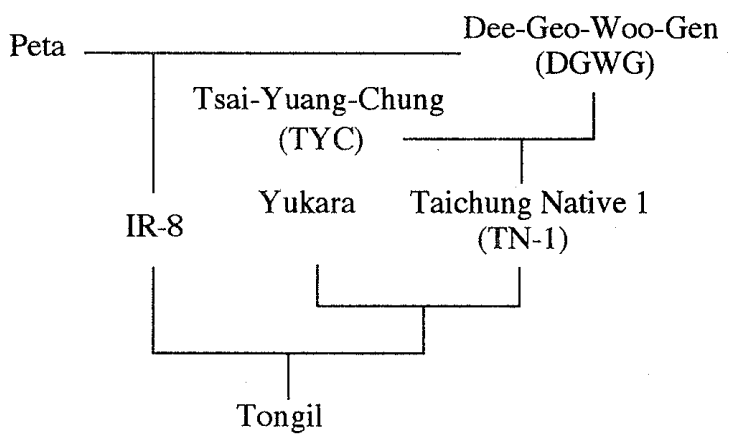

Fig. 1. Rice cultivars used in the experiment. and Tsai-Yuang-Chung (TYG) are indica cultivars.

After sieving air-dried sandy loam soil in $2 \mathrm{~mm}$ mesh, $0.25 \mathrm{~g}$ of compound synthetic fertilizer $(\mathrm{N}, 12 \% ; \mathrm{P}, 16 \% ; \mathrm{K}, 14 \%)$ was mixed with $2.6 \mathrm{~kg}$ of the soil per one root box. They were then placed in the root boxes using the procedure proposed by Kono et al. ${ }^{16)}$ Thereafter, root boxes were soaked in a water pool until the soil was saturated. Half of the boxes were allowed to drain to field capacity on the day before sowing. The following two treatments for different soil moisture conditions were prepared:submerged treatment, whereby submerged conditions were continued throughout the experiment ; upland treatment, once a week root boxes were irrigated in the way described above. Seeds were soaked in water at $30^{\circ} \mathrm{C}$ for 48 hours as a pregermination treatment. Thereafter, the seeds of each cultivar (seven seeds per root box) were sown in a row with the same distance $(3 \mathrm{~cm})$, on May 5, 1995. Seven replicate root boxes were used to minimize the effect of sowing position by shifting the seven cultivars one-by-one.

Rice plants were sampled three weeks after growing in a vinyl-house. The shoots were separated from the soil surface, then leaf age and number of tillers were recorded. After drying at $80^{\circ} \mathrm{G}$ for 72 hours, shoot dry weight was measured. The root systems were sampled using the revised root box-pinboard method ${ }^{16)}$. Thereafter, they were fixed in FAA solution (70\% Ethanol: Formalin: Acetic acid $=18$ : 1:1 parts by volume), and were stained with $0.25 \%$ Coomassie Brilliant Blue $\mathrm{R}$ aqueous solution for three days.

The root systems were separated into a seminal root and nodal roots. Only the number was recorded on the nodal roots. Three seminal root systems on each cultivar and treatment, which showed intermediate growth, were selected for quantitative analysis. First, root sample was converted to digitized image and fractal dimension $(D)$, which is thought to be a parameter describing root distribution quantitatively ${ }^{27)}$, was obtained using the procedure previously described ${ }^{13)}$. As the $D$ value is larger, root distribution is judged to be more complex. Next, the seminal root axis length and the number and length of all the lateral roots were measured with a ruler. The lateral 
roots were classified into two categories, namely L-type, which is long, thick, and produces higher order branching, and S-type, which is short, slender and has no branching ${ }^{17,28)}$. In summery, we obtained the total number (equivalent to magnitude, $\mu$ ) and length of a root system. At the same time with measuring, the architecture of the root system was sketched manually for topological and geometrical analyses.

For topological analysis, altitude $(a)$ and total external pathlength $(P e)$ were determined $^{8,9,13)}$ based on the sketch of a root system which was manually drawn, and we calculated the ratio of $a$ and $P e$ to each maximum value, i. e., $a / \operatorname{Max}(P e)$ as topological indices reported before ${ }^{14)}$. When the branching pattern of a root system is the complete herringbone type, in which no lateral root of more than first order emerges, both of the ratios are at a maximum $(=1)$, and the ratios decrease as the branching pattern becomes complicated.

The geometrical variables, average link lengths were separately calculated for external and internal links. The external link is where the one edge is the root tip, and the internal link is without a root tip ${ }^{8,9,13)}$. The average length of each link in a root system was calculated as follows using the number and length of roots, and the length from a root tip to the nearest branching point of a seminal root axis and L-type roots (unbranched zone).

$$
\begin{aligned}
\text { External link length } & =\frac{\text { Total length of external link }}{\text { Total number of external link }} \\
& =\frac{\text { Total length of S-type lateral root and unbranched zone }}{\mu} \\
\text { Internal link length } & =\frac{\text { Total length of internal link }}{\text { Total number of internal link }} \\
& =\frac{\text { Total root length }- \text { Total length of external link }}{\mu-1}
\end{aligned}
$$

Hence, the external link length is affected by elongation of S-type lateral roots and the unbranched zone of L-type laterals and seminal root axis, while the internal link length reflects the interval between the bases of adjacent lateral roots, which is further equivalent to a reciprocal number of branching density.

\section{Results}

The number of stems, leaf age, dry weight of shoot and nodal root number are shown in Table 1 . There were significant cultivar variations in all four characters (Table 2). In comparing the two treatments, drastic change occurred in the number of stem and nodal roots, whereas such differences between treatments were not observed in leaf age and shoot dry weight (Table 1). Thus, the main effect of soil moisture was significant in the number of

\begin{tabular}{|c|c|c|c|c|c|c|c|c|}
\hline Characters & Treatment & DGWG & IR-8 & TN-1 & Peta & Tongil & TYC & Yukara \\
\hline \multirow[t]{2}{*}{ Tiller number } & Upland & $3.0 \mathrm{c}$ & $2.0 \mathrm{ab}$ & $2.4 \mathrm{~b}$ & $1.9 \mathrm{a}$ & $1.7 \mathrm{a}$ & $1.9 \mathrm{a}$ & $2.1 \mathrm{ab}$ \\
\hline & Paddy & $1.6 \mathrm{c}$ & $1.0 \mathrm{a}$ & $1.1 \mathrm{ab}$ & $1.0 \mathrm{a}$ & $1.0 \mathrm{a}$ & $1.4 \mathrm{bc}$ & $1.2 \mathrm{ab}$ \\
\hline \multirow[t]{2}{*}{ Leaf age } & Upland & $5.4 \mathrm{~b}$ & $5.3 \mathrm{ab}$ & $5.2 \mathrm{ab}$ & $5.4 \mathrm{~b}$ & $5.2 \mathrm{ab}$ & $5.1 \mathrm{a}$ & $5.3 \mathrm{ab}$ \\
\hline & Paddy & $5.4 \mathrm{~cd}$ & $5.1 \mathrm{ab}$ & $5.4 \mathrm{~d}$ & $5.3 \mathrm{bcd}$ & $5.2 \mathrm{bc}$ & $5.0 \mathrm{a}$ & $5.4 \mathrm{~d}$ \\
\hline \multirow{2}{*}{$\begin{array}{c}\text { Shoot dry } \\
\text { weight (mg) }\end{array}$} & Upland & $56.7 \mathrm{bc}$ & $60.8 \mathrm{c}$ & $60.7 \mathrm{c}$ & $64.6 \mathrm{c}$ & $58.3 \mathrm{bc}$ & $46.0 \mathrm{a}$ & $50.0 \mathrm{ab}$ \\
\hline & Paddy & $63.4 \mathrm{~d}$ & $54.8 \mathrm{bc}$ & $60.9 \mathrm{~cd}$ & $61.2 \mathrm{~cd}$ & $60.0 \mathrm{~cd}$ & $48.3 \mathrm{a}$ & $50.0 \mathrm{ab}$ \\
\hline \multirow{2}{*}{$\begin{array}{l}\text { Nodal root } \\
\text { number }\end{array}$} & Upland & $16.7 \mathrm{bc}$ & $15.3 \mathrm{~b}$ & $18.8 \mathrm{~d}$ & $17.5 \mathrm{~cd}$ & $15.3 \mathrm{~b}$ & $13.2 \mathrm{a}$ & $12.7 \mathrm{a}$ \\
\hline & Paddy & $12.2 \mathrm{~b}$ & $9.0 \mathrm{a}$ & $13.0 \mathrm{~b}$ & $9.0 \mathrm{a}$ & $8.0 \mathrm{a}$ & $8.5 \mathrm{a}$ & $8.6 \mathrm{a}$ \\
\hline
\end{tabular}
stems and nodal roots, but not in the other

Table 1. Comparison of the characters of shoot and nodal root of rice plant grown in a root box for three weeks with different soil moisture conditions.

Same letters adjacent to each value mean no significant difference among cultivars at $5 \%$ level according to Duncan's multiple range test.

DGWG: Dee-Geo-Woo-Gen, TYC: Tsai-Yuang-Chung. 
Table 2. Effects of soil moisture conditions, cultivar and their interaction on the shoot characters of rice grown in a root box for three weeks shown by F-ratio from two-way analysis of variance.

\begin{tabular}{rcrc}
\hline $\begin{array}{r}\text { Soil moisture } \\
(1,84)\end{array}$ & $\begin{array}{r}\text { Cultivar } \\
(6,84)\end{array}$ & $\begin{array}{c}\text { Interaction } \\
(6,84)\end{array}$ \\
\hline Tiller number & $142.87 * * *$ & $8.39 * * *$ & $2.86 *$ \\
Leaf age & 0.14 & $6.23 * * *$ & 2.19 \\
Shoot dry weight & 0.27 & $5.19 * * *$ & 0.86 \\
Nodal root number & $155.18 * * *$ & $10.53 * * *$ & 0.78 \\
\hline
\end{tabular}

$*, * * *: 5,0.1 \%$ level of significance.

Degrees of freedom for each source are given in parentheses.

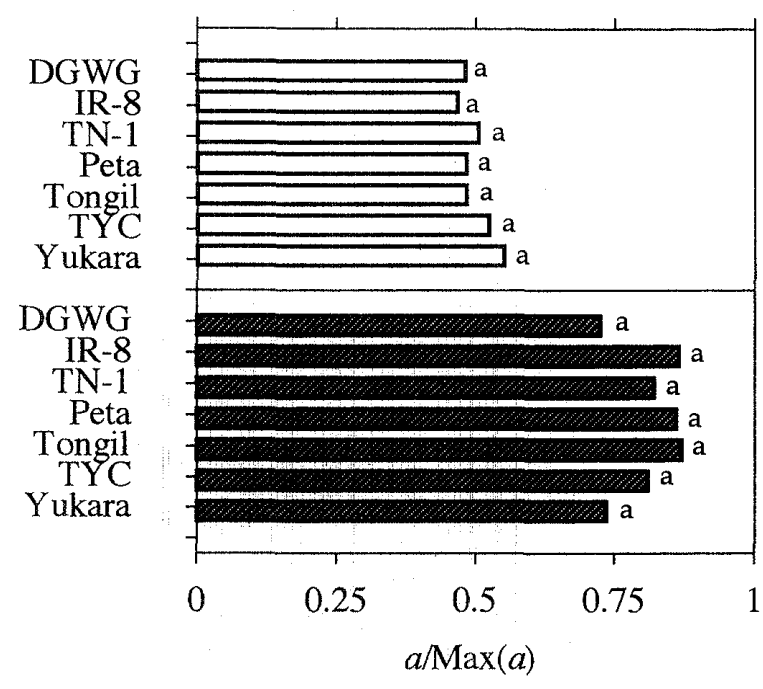

Fig. 2. Comparison of topological index, $a / \operatorname{Max}$ (a) of seminal root systems among seven rice cultivars grown in a root box with two different soil moisture conditions for three weeks. Alphabet letters are the same as those in Table 1. Details of the topological index are referred to Izumi et al. ${ }^{14)}$

$$
\square: \text { Upland, : Paddy. }
$$

characters (Table 2). Significant interaction of two factors was only found in the stem number.

As in the shoot and nodal root characters, the main effects and interaction of two factors on the characters of the seminal root system are shown in Table 3. The effects of soil moisture on all characters except for total root length were highly significant. This indicated that most of the characters which determine root system architecture were considerably different between the treatments, whereas the total amount of elongation of the lateral roots was similar.
Table 3. Effects of soil moisture conditions, cultivar and their interaction on the root characters of rice grown in a root box for three weeks shown by F-ratio from two-way analysis of variance.

\begin{tabular}{cccl}
\hline & $\begin{array}{c}\text { Soil moisture } \\
(1,28)\end{array}$ & $\begin{array}{c}\text { Cultivar } \\
(6,28)\end{array}$ & $\begin{array}{l}\text { Interaction } \\
(6,28)\end{array}$ \\
\hline SRAL & $549.30 * * *$ & $5.11 * * *$ & $4.04 * *$ \\
TRN & $486.57 * * *$ & $7.55 * * *$ & $5.35 * * *$ \\
TRL & 2.71 & $15.15 * * *$ & $3.73 * *$ \\
a $/ \mathrm{Max}(a)$ & $238.32 * * *$ & 0.90 & 2.25 \\
$P e / \mathrm{Max}(\mathrm{Pe})$ & $281.16 * * *$ & 1.34 & 1.66 \\
$D$ & $73.28 * * *$ & $3.57 * *$ & 1.38 \\
ELL & $1550.31 * * *$ & $6.31 * * *$ & $4.47 * *$ \\
ILL & $13.97 * * *$ & $3.16 *$ & $2.67 *$ \\
\hline SRAL, seminal root axis length; \\
TRN, total root number; TRL, total root length; \\
ELL, external link length; ILL, internal link length. \\
* **, ***: 5, 1, 0.1\% level of significance. \\
Degrees of freedom for each source are given \\
in parentheses.
\end{tabular}

Fig. 2 shows one of the topological indices, $a / \operatorname{Max}(a)$, of seminal root systems of seven cultivars in two treatments. The value was larger in the paddy than in the upland treatment, which meant the branching pattern in the paddy treatment was simpler and closer to the herringbone type as compared with the upland treatment. On the other hand, no significant cultivar variation was found within each treatment, that is, the topological branching pattern was almost similar among the cultivars. The other topological index, $\mathrm{Pe} / \mathrm{Max}$ $(P e)$ was significantly smaller in DGWG, IR8 and TYG than Yukara in the upland treatment. However, an almost similar trend was found as in $a / \operatorname{Max}$ ( $a$ ) (data not shown).

The fractal dimension $(D)$ of seminal root systems shown in Fig. 3 was higher in the paddy than in the upland treatment, which indicated the spatial distribution of lateral roots was more intricate in paddy than in upland treatment. Significant cultivar variation was found in both treatments. TYG and Yukara showed the lowest $D$ value in upland and paddy treatment, respectively, and $D$ in these cultivars was also low in the other treatment.

The average link lengths are shown in Fig. 4. It was clear that the external link (upper) was much longer than the internal link (lower) in both treatments. The external link 
length drastically changed in relation to soil moisture. In paddy treatment, it was nearly three times longer than in upland treatment in all of the cultivars (upper). On the other hand, the difference in the internal link length between the treatments was not evident (lower) as shown in the smaller main effect of moisture (Table 3). Among the cultivars, Peta showed the shortest external link length in upland treatment, while TYG and Yukara in paddy treatment were the shortest, and no common trend was found (Fig. 4-upper). On the other hand, Peta had the shortest internal link length in both treatments (lower). Hence, this cultivar was characterized by the dense branching of lateral roots. Although significant variations were observed among other

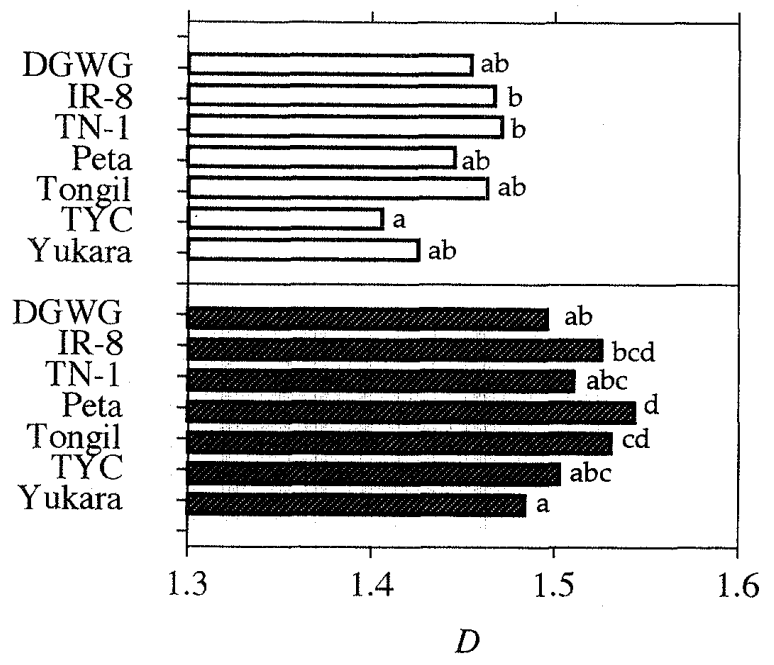

Fig. 3. Comparison of fractal dimension $(D)$ of seminal root systems among seven rice cultivars grown in a root box with two different soil moisture conditions for three weeks. Alphabet letters are the same as those in Table 1.

$$
\square \text { : Upland, } \text { : Paddy. }
$$

cultivars, it was difficult to find a common trend such as external link length.

Next, the developmental root characters are

DGWG
IR-8
TN-1
Peta
Tongil
TYC
Yukara
DGWG
IR-8
TN-1
Peta
Tongil
TYC
Yukara
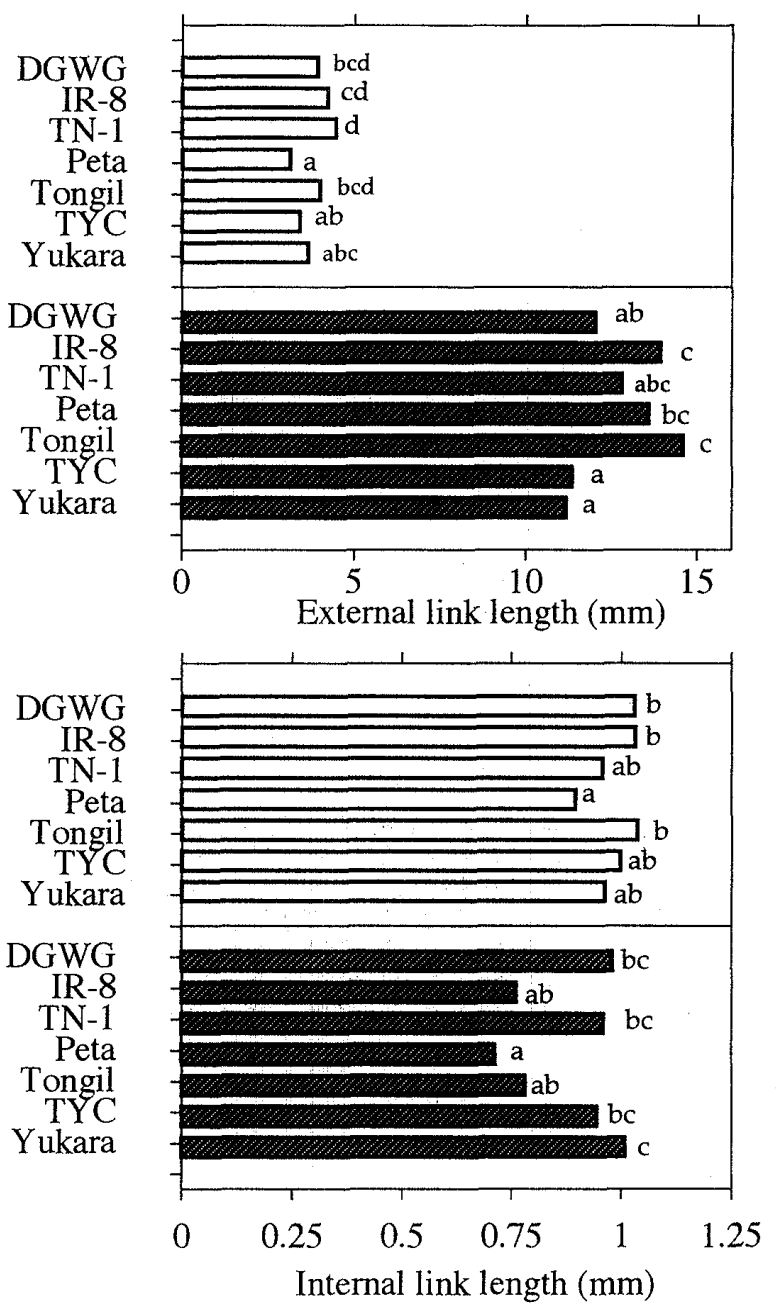

Fig. 4. Comparison of external (upper) and internal (lower) link length of seminal root systems among seven rice cultivars grown in a root box with two different soil moisture conditions for three weeks. Alphabet letters are the same as those in Table 1.

$$
\square \text { : Upland, 国: Paddy. }
$$

Table 4. Comparison of seminal root axis length, total root number, and total length of seminal root systems among seven rice cultivars grown in a root box for three weeks with different soil moisture conditions.

\begin{tabular}{ccccccccc}
\hline Characters & Treatment & DGWG & IR-8 & TN-1 & Peta & Tongil & TYC & Yukara \\
\hline Seminal root & Upland & $342.0 \mathrm{c}$ & $317.0 \mathrm{~b}$ & $347.7 \mathrm{c}$ & $346.7 \mathrm{c}$ & $332.0 \mathrm{bc}$ & $299.7 \mathrm{ab}$ & $273.7 \mathrm{a}$ \\
axis length (mm) & Paddy & $191.7 \mathrm{ab}$ & $187.0 \mathrm{ab}$ & $204.3 \mathrm{bc}$ & $193.0 \mathrm{ab}$ & $198.7 \mathrm{~b}$ & $219.3 \mathrm{c}$ & $181.0 \mathrm{a}$ \\
\hdashline Total root & Upland & $1110.0 \mathrm{~cd}$ & $1121.3 \mathrm{~cd}$ & $1200.7 \mathrm{~cd}$ & $1310.3 \mathrm{~d}$ & $1002.0 \mathrm{bc}$ & $846.7 \mathrm{ab}$ & $746.7 \mathrm{a}$ \\
number & Paddy & $459.7 \mathrm{~b}$ & $367.7 \mathrm{a}$ & $381.0 \mathrm{a}$ & $403.7 \mathrm{~b}$ & $381.7 \mathrm{a}$ & $378.7 \mathrm{a}$ & $346.3 \mathrm{a}$ \\
\hdashline Total root & Upland & $5491.0 \mathrm{bc}$ & $5839.8 \mathrm{bc}$ & $6484.0 \mathrm{c}$ & $5230.5 \mathrm{~b}$ & $5030.3 \mathrm{~b}$ & $3723.8 \mathrm{a}$ & $3445.5 \mathrm{a}$ \\
length $(\mathrm{mm})$ & Paddy & $5940.0 \mathrm{c}$ & $5387.2 \mathrm{bc}$ & $5245.5 \mathrm{bc}$ & $5771.5 \mathrm{c}$ & $5868.3 \mathrm{c}$ & $4652.7 \mathrm{ab}$ & $4194.7 \mathrm{a}$ \\
\hline
\end{tabular}

See Table 1. 
shown (Table 4). Seminal root axis length was longer in upland treatment than paddy treatment in all of the cultivars, and significant variations were found among some cultivars. In total root number, significant cultivar variation was found in upland treatment, i.e., Yukara, TYC and Tongil were relatively smaller than in the other cultivars. On the other hand, the variation was relatively small in paddy treatment and was only significant between DGWG or Peta and five other cultivars. Comparing the average values of each cultivar between the treatments, the total root number was two-or-three times larger in upland treatment than in paddy treatment.

Because the difference in total root length between the treatments was smaller than number, the main effect of soil moisture showed no significance (Table 3). On the other hand, the main effect of cultivars in total root length was the biggest among the F-values, and showed a quite smaller interaction compared with main effect. Hence, it was relatively easy to find a common trend in the cultivar variation for both treatments. Among cultivars, TYC and Yukara had a significantly shorter total length in upland treatment. A similar trend was also observed in the paddy treatment, though the variation was smaller.

In the upland treatment, the main reason for shorter total length in these two cultivars seemed to be smaller total root number because the trends of cultivar variation in total number and length were similar (Table 4). This was due to the fact that both external and internal link lengths, which are equivalent to average length of lateral roots and intervals of branching, were relatively similar among cultivars (Fig. 4). On the other hand, the cultivar variation in total root number was small in paddy treatment (Table 4), whereas that in the average link length was large (Fig. 4). We especially noticed that the external link length in the paddy treatment was short in TYC and Yukara (upper). Thus, low elongation ability of lateral roots was the main reason for smaller total root length in these two cultivars. Furthermore, it was possible that the relatively large variation in internal link length in the paddy treatment as compared with the upland treatment (lower), which reflects the branching density of lateral roots, might also cause cultivar variation in root system archi- tecture.

To summarize the results, the architecture was characterized as a more complex branching pattern in upland treatment, and a longer external link length in paddy treatment. Hence, root system development lays emphasis on the branching (emergence) of lateral roots in the former, and their elongation in the latter treatment. Next, the cultivar variation in total root length was mainly due to variation in total root number in upland treatment, and average external link length in paddy treatment, which are similar to those emphasized in root system development under the two soil moisture conditions.

\section{Discussion}

\section{Environmental effect}

Normally, the branching of lateral roots of rice in upland conditions is more vigorous than in submerged conditions s $^{2,3,11,15,17)}$ unless drought stress is so severe that quantitative root growth is inhibited, as in some cases ${ }^{1,23)}$. It is especially reported that the emergence of L-type lateral roots is more abundant in upland or low soil moisture conditions ${ }^{11,15,17)}$. In our study, too, the number of L-type first order lateral roots and concomitant second order lateral roots in upland treatment was greater than in paddy treatment regardless of cultivars (data not shown). We clearly recognize the difference in root system architecture between the treatments by using mathematical root parameters, such as topological indices and external link length.

The effects of soil moisture on topological indices and average link lengths have been discussed before ${ }^{4,5,8,9,10)}$, but the opposite results were often reported. Namely, as the watering rate decreased the root system showed higher topological indices ${ }^{4,5,9}$ ) (simpler branching pattern) or longer external link length ${ }^{4,5,10)}$. In such cases, root growth was probably suppressed by drought stress as discussed in the previous paragraph. Furthermore, we suppose that the opposing effect of soil moisture on these parameters resulted from the difference in plant species or moisture level in an experiment. Any universal conclusion therefore cannot be induced before considering other environmental factors, such as oxygen concentration or redox potential in soil.

Regardless, the difference in topological 
indices between the treatments (Fig. 2) corresponded well with the difference in the number of lateral roots (Table 4). On the other hand, the difference in internal link length was not clear (Fig. 4-lower). These results indicate that soil moisture mainly affected the degree on how lateral root emergence advanced on higher order, while the branching density of lateral roots was less flexible against soil moisture.

No information has been given to date about soil moisture on the fractal dimension of root system. In this study, $D$ was always higher in paddy than upland treatment (Fig. 3 ). However, the difference in topological indices between the treatments indicated that the architecture was topologically more complex in upland compared to paddy treatment (lower topological index, Fig. 2). Thus, fractal dimension tended to correspond with not the degree of branching but the elongation of lateral roots, which was shown in external link length (Fig. 4-upper) in the case of rice as we previously reported ${ }^{13)}$.

\section{Cultivar variation}

In this study, ranges in cultivar variations in all of the developmental root characters were smaller in paddy treatment than in upland treatment (Table 4). Sirohi et al. ${ }^{24)}$ also reported that varietal difference in lateral root growth of wheat was markedly expressed in unirrigated conditions only. The reason is unclear, but the cultivar variation in phenotypic plasticity ${ }^{22)}$ against soil moisture was probably the reason for larger variation in root system development in upland treatment, so that further research on phenotypic plasticity will be needed.

Recently, Morita et al. $^{20)}$ quantitatively analyzed the root system morphology of four rice cultivars in the paddy field, and found that the morphology could be characterized using the two indices of root amount and root depth index. Furthermore, they pointed out that the former index was determined by the number of nodal roots and mean root length. In our results, the cultivar variation in total root length, which is equivalent to root amount, corresponded with variation in external link length, which is the parameter for mean length of lateral roots. Though the study of Morita et al. mentioned the mean length of nodal roots and ours mentioned that of lateral
Table 5. Correlation coefficients between fractal dimension and three parameters of seminal root system of rice grown under two different soil moisture conditions, which were calculated with the mean values of seven cultivars.

\begin{tabular}{lllc}
\hline Treatment & TRL & ELL & $a / \operatorname{Max}(a)$ \\
\hline Upland & $0.901 * *$ & $0.727 \dagger$ & $-0.712 \dagger$ \\
Paddy & 0.648 & $0.872 * *$ & $0.898 * *$ \\
\hline TRL, total root length; ELL, external link length. \\
$\dagger, * *: 10,1 \%$ level of significance.
\end{tabular}

roots, we had the similar finding that root elongation determined root amount in paddy field. However, in upland treatment, external link length was less important for total root length. Therefore, we suppose that the method for characterization of architecture with several parameters should be altered because the growth strategy of the seminal root system was changed by environmental conditions.

As well as the effect of soil moisture, we tried to evaluate the cultivar variation with mathematical root parameters. Among the parameters, we especially noticed the fractal dimension because it is easier to obtain than the others. In upland treatment, the pattern of cultivar variation in $D$ seemed to be similar to that in total root length (Fig. 3 and Table 4). Actually, the correlation coefficient between $D$ and total root length calculated with the mean values of seven cultivars was significant in upland treatment, but not in paddy treatment (Table 5). As already showed, $D$ reflected the elongation of lateral roots in rice and external link length positively correlated with $D$ in both treatments. However, correlation coefficients between $D$ and the topological index, $a / \mathrm{Max}$ (a) were significant but opposite for the treatments, i. e., negative in upland and positive in paddy treatment. Tatsumi ${ }^{27)}$ reported that $D$ does not solely reflect quantitative characters such as root length but also contains other information on branching density or distribution of roots. Hence, we further assume that the significance of $D$ should be altered with the growth strategy of root systems determined by growth conditions, even in the same plant species.

Topological indices scarcely showed cultivar variation in both treatments (Fig. 2), whereas significant variation was observed in internal link length (Fig. 4-lower). This indicated that 
the cultivar variation was not expressed in the degree of higher branching order but in the branching density of lateral roots. Considering also the different responses of these two features against soil moisture described above, we suppose that they are utterly different characters and needed to be evaluated individually.

As discussed above, we found potential for the illumination of morphological differences in rice seminal root systems in relation to cultivar variation and environmental effects by using the mathematical parameters together with the conventionally-used developmental characters. However, we also found that to exactly evaluate root system architecture, "complexity of branching pattern" must be understood with both parameters, such as topological indices and branching density, and that the significance of fractal dimension must be appreciated according to the growth strategy of the root system.

\section{References}

1. Abe, J., S. Yamamoto, S. Morita and S. Akita 1994. Effects of soil moisture on the development of lateral roots in rice (Oryza sativa L.). Jpn. J. Crop Sci. 63 (extra 1) : 200-201*.

2. Alberda, Th. 1953. Growth and root development of lowland rice and its relation to oxygen supply. Plant Soil $5: 1-28$.

3. Banba, H. and H. Ohkubo 1981. Relationship between root distribution of upland crops and their yield. III. Influence of soil moisture levels on root distribution and root dry matter of uplandcultured paddy rice, crossbred rice of paddy rice and upland rice, and upland rice. Jpn. J. Crop Sci. $50: 1-7^{* *}$.

4. Berntson, G. M. and F. I. Woodward 1992. The root system architecture and development of Senecio vulgaris in elevated carbon dioxide and drought. Funct. Ecol. $6: 324-333$.

5. __ 1994. Modelling root architecture : are there tradeoffs between efficiency and potential of resource acquisition ? New Phytol. 127:483493.

6. Bray, R. H. 1954. A nutrient mobility concept of soil-plant relationship. Soil Sci. $78: 9-22$.

7. Chang, T. T., G. C. Loresto and O. Tagumpay 1972. Agronomic and growth characteristics of upland and lowland rice varieties. In IRRI ed., Rice Breeding. Int. Rice Res. Inst., Los Baños, Philippines. 645-661.

8. Fitter, A. H. 1985. Functional significance of root morphology and root system architecture. In Fitter, A. H. et al. eds., Ecological Interaction in
Soil. Blackwell, Oxford. 87-106.

9. 1986. The topology and geometry of plant root systems : Influence of watering rate on root system topology in Trifolium pratense. Ann. Bot. 58 : $91-101$.

10. — and T. R. Stickland 1992. Architectural analysis of plant root systems. III. Studies on plants under field conditions. New Phytol. 121 : $243-248$.

11. Fujii, Y. 1959. On the development of branchroots on successive nodes of rice plants. Proc. Crop Sci. Soc. Japan $28: 15-16^{* *}$.

12. Hasegawa, H., T. Kon and Y. Kono 1994. Root development of $\mathrm{F}-1$ rice hybrid and parents as affected by nitrogen concentration of culture solution. Soil Sci. Plant Nutr. $40: 531-537$.

13. Izumi, Y., Y. Kono, A. Yamauchi and M. Iijima 1995. Analysis of timecourse changes in root system morphology of rice in excised root culture. Jpn. J. Grop Sci. 64 : 636-643.

14. topological indices with seminal root system development of rice. Jpn. J. Crop Sci. $65: 303-308$.

15. Kawata, S. and H. Shibayama 1966. Types of branching in lateral roots of rice plants. Proc. Crop Sci. Soc. Japan 35:59-70**.

16. Kono, Y., A. Yamauchi, T. Nonoyama, J. Tatsumi and N. Kawamura 1987. A revised experimental system of root-soil interaction for laboratory work. Environ. Control in Biol. 25 : 141-151.

17. - 1993. Soil factors and root morphology. In Matsuo, T. and K. Hoshikawa eds., Science of the Rice Plant. Vol. 1 Morphology. Food and agriculture policy research center, Tokyo. 507525.

18. Lynch, J. 1995. Root architecture and plant productivity. Plant Physiol. 109: 7-13.

19. Morita, S. and K. Yamazaki 1993. Root system. In Matsuo, T. and K. Hoshikawa eds., Science of the Rice Plant. Vol. 1 Morphology. Food and agriculture policy research center, Tokyo. 161186.

20. —— S. Yamada and J. Abe 1995. Analysis on root system morphology in rice with reference to varietal differences at ripening stage. Jpn. J. Crop Sci. $64: 58-65^{* * *}$.

21. Nagai, T. and H. Hirota 1958. Cultivated rice varieties viewed from root characters. (I) Some ecological characters of rice plants continuously grown in nursery. (II) Root diameter, rooting and others. Proc. Crop Sci. Soc. Japan 27:217$220 * *$.

22. O'Toole, J. G. and W. K. Bland 1987. Genotypic variation in crop plant root systems. Adv. Agron. $41: 91--145$. 
23. Reddy, T. Y. and R. Kuladaivelu 1992. Root growth of rice (Oryza sativa) as influenced by soil-moisture regime and nitrogen. Indian J. Agron. 37 : 694-699.

24. Sirohi, G. S., D. C. Uprety and O. P. S. Tomar 1978. Studies on the root growth of wheat varieties. Indian J. Plant Physiol. 21 : 185-196.

25. Tanaka, N. 1974. The study of crop roots. Jpn. J. Crop Sci. $43: 291-316^{*}$.

26. Tanaka, S., A. Yamauchi and Y. Kono 1995. Root system morphology of four rice cultivars: response of different component roots to nitrogen application. Jpn. J. Crop Sci. 64 : 148-155.

27. Tatsumi, J. 1995. Fractal geometry in root systems : quantitative evaluation of distribution pattern. Jpn. J. Crop Sci. 64 : 50-57***.

28. Yamauchi, A., Y. Kono and J. Tatsumi 1987.
Quantitative analysis on root system structures of upland rice and maize. Jpn. J. Crop Sci. $56: 608$ $-617$.

29. Yoshida, S., D. P. Bhattacharjee and G. S. Cabuslay 1982. Relationship between plant type and root growth in rice. Soil Sci. Plant Nutr. 28 : 473482.

30. - and S. Hasegawa 1982. The rice root system : its development and function. In IRRI eds., Drought Resistance in Crops with Emphasis on Rice. Int. Rice Res. Inst., Los Baños, Philippines. 97-114.

* In Japanese.

** In Japanese with English summary.

*** In Japanese with English abstract. 